Tersedia online di:http://ejournal-balitbang.kkp.go.id/index.php/jkpi
e-mail:jkpi.puslitbangkan@gmail.com
JURNAL KEBIJAKANPERIKANANINDONESIA
Volume 10 Nomor 1 Mei 2018
p-ISSN: 1979-6366
e-ISSN: 2502-6550
Nomor Akreditasi Kementerian RISTEKDIKTI: 21/E/KPT/2018

\title{
DINAMIKA KELEMBAGAAN DAN IMPLIKASINYA DALAM PENGELOLAAN PERIKANAN KEPITING BAKAU DI OHOI EVU KABUPATEN MALUKU TENGGARA
}

\section{INSTITUTIONAL DYNAMICS AND IMPLICATIONS ON MANGROVE CRABS FISHERY MANAGEMENT AT THE OHOI EVU SOUTHEAST DISTRICT}

\author{
James Abrahamsz ${ }^{1,2^{*}}$, Marvin M. Makailipessy ${ }^{3}$ dan Imanuel M. Thenu ${ }^{3}$ \\ ${ }^{1}$ Pusat Pembelajaran-Pengelolaan Perikanan dengan Pendekatan Ekosistem, Universitas Pattimura, Jalan Mr. Chr. Soplanit-Poka, \\ Kota Ambon, Maluku, Indonesia \\ ${ }^{2}$ Fakultas Perikanan dan Ilmu Kelautan, Universitas Pattimura, Jalan Mr. Chr. Soplanit-Poka, Kota Ambon, Maluku, Indonesia \\ ${ }^{3}$ Politeknik Perikanan Tual, Jl. Raya Langgur-Sathean, Km 06, Sathean, Kei Kecil, Kabupaten Maluku Tenggara, Maluku, Indonesia \\ Teregistrasi I tanggal: 17 Oktober 2017; Diterima setelah perbaikan tanggal: 03 Mei 2018; \\ Disetujui terbit tanggal: 21 Mei 2018
}

\begin{abstract}
ABSTRAK
Pengelolaan perikanan kepiting di Kawasan Konservasi Pulau Kei Kecil dan Perairan Sekitarnya di Kabupaten Maluku Tenggara Provinsi Maluku telah dilakukan. Salah satunya melalui pengembangan kelembagaan pengelola di Ohoi Evu, Kecamatan Hoat Sorbay. Inisiatif pengembangan model pengelolaan perikanan kepiting berbasis masyarakat dimulai dengan pembentukan kelompok nelayan Sinar Abadi. Kajian bertujuan menilai dinamika, status dan perkembangan kelembagaan di masyarakat dalam mendukung pengelolaan perikanan kepiting secara berkelanjutan. Dinamika kelembagaan dianalisis melalui penilaian domain kelembagaan dalam Ecosystem Approach to Fisheries Management (EAFM) dan pendekatan flag model. Status dan perkembangan kelembagaan dianalisis dengan pendekatan Institutional Development Framework (IDF). Penelitian ini menemukan dinamika kelembagaan pengelola perikanan kepiting bakau di Ohoi Evu tergolong dalam kategori sedang. Status kelembagaan cukup baik, berada pada tahap pemantapan dan kebutuhan pengembangan kelembagaan mendesak. Implikasi pengembangannya adalah peningkatan kapasitas kelembagaan dalam pengelolaan perikanan kepiting yang bertanggungjawab, penetapan dan implementasi Rencana Pengelolaan Perikanan Kepiting, serta penguatan sumberdaya manajemen kelompok dan kemitraan.
\end{abstract}

Kata Kunci: Kepiting bakau; pengelolaan perikanan; status kelembagaan; dinamika kelembagaan

\section{ABSTRACT}

The management of crab fishery in the Coastal and Small Islands Conservation Area of Kei Kecil Island and the surrounding Waters of Southeast Maluku Regency of Maluku Province has been conducted. One of them is through the development of management institution in Ohoi Evu, Hoat Sorbay Sub-district. The initiative to develop a community-based crab fisheries management model begins with the formation of the Sinar Abadi fishing group. The study aims to assess the dynamics, status and institutional development in the community to supporting the sustainable management of crab fisheries. The institutional dynamics are analyzed through the assessment of institutional domains of the Ecosystem Approach to Fisheries Management (EAFM) and the flag model approach. Institutional status and development are analyzed by using Institutional Development Framework (IDF) approach. Results of the analysis showed that institutional dynamics of crab fishery management in Ohoi Evu belong to medium category. The institutional status is quite good, at the status of consolidation stage and the urgent institutional development needs. The implications are enhancement of institutional capacity in responsible fishery management of crabs, establishment and implementation of the Crab Fisheries Management Plan, and strengthening of institutional management resources and partnership.

Keywords: Mangrove crabs; fisheries management; institutional; dynamics

Korespondensi penulis:

e-mail: james.abrahamsz@fpik.unpatti.ac.id

Telp. +6281343205406 


\section{PENDAHULUAN}

Kawasan Konservasi Pesisir dan Pulau-Pulau Kecil (KKP3K) Pulau Kei Kecil dan Perairan Sekitarnya di Kabupaten Maluku Tenggara Provinsi Maluku, telah ditetapkan dengan Kepmen KP Nomor 6 Tahun 2016. Pada KKP3K ini terdapat kawasan hutan mangrove yang cukup luas (827,88 ha), yaitu hutan mangrove Hoat Sorbay. Kawasan ini merupakan kawasan dimana pengelolaan perikanan kepiting bakau telah dilakukan. Salah satu ohoi (desa) yang telah mengembangkan model pengelolaan perikanan kepiting berbasis masyarakat adalah Ohoi Evu. Pengelolaan berbasis masyarakat dikembangkan melalui dukungan pengembangan kelompok pengelola, yaitu kelompok Sinar Abadi.

Pengembangan kelompok pengelola mengikuti arahan Better Management Practices (BMP) Kepiting Bakau, sebagai upaya meningkatkan posisi tawar dan membina kebersamaan untuk menjaga keberlanjutan usaha penangkapan kepiting bakau. Manfaatnya antara lain: 1) mendiskusikan kegiatan-kegiatan penangkapan; 2) sebagai pusat informasi anggota dan masyarakat umum; 3) mengumpulkan dan menyimpan data-data pencatatan hasil tangkapan; serta 4) sebagai tempat pengaduan dan mediasi konflik pemanfaatan (Tim Perikanan WWF-Indonesia, 2015).

Pengembangan kelompok pengelolaan diarahkan untuk menjawab berbagai persoalan perikanan kepiting di Indonesia, khususnya di Wilayah Pengelolaan Perikanan (WPP) 714. Suman et al. (2016) memberikan catatan penting bahwa kelompok sumber daya ikan yang mengalami kondisi overfishing paling tinggi di Indonesia adalah kelompok udang penaeid, lobster, kepiting dan rajungan, mencapai $63 \%$ dari kondisi overfishing saat ini. Selanjutnya dikemukakan untuk kelompok perikanan ini, pada WPP 714 harus dikurangi upaya tangkap.

Eksistensi KKP3K dengan potensi perikanan kepiting dan fakta overfishing pada kelompok perikanan ini menunjukkan adanya kebutuhan pengelolaan untuk mendukung pemanfaatan berkelanjutan. Demikian halnya persoalan kelembagaan yang baru terbentuk, masih harus dinilai dan diketahui implikasinya dalam pengelolaan perikanan kepiting.

Pentingnya aspek kelembagaan dalam pengelolaan perikanan yang efektif (Sutinen, 1999) dan kolaboratif (Cinner et al., 2009; 2012), tergambar dari dua nilai yang dikandungnya, sistem nilai atau norma dan organisasi, melalui identifikasi masalah dan isu pengelolaan, respons kelembagaan, pengorganisasian kelembagaan pengelola, dan tindakan pengelolaan (Dahuri et al., 2004; Abrahamsz \& Wurlianty, 2016). Kelembagaan ditempatkan dalam komponen sistem pengelolaan karena dinamika kelembagaan memberikan pengaruh kuat dalam suatu sistem pengelolaan perikanan (Charles, 2001). Pendekatan ini dapat diterapkan pada setiap wilayah pengelolaan perikanan, terutama wilayah yang memiliki kawasan konservasi (Abrahamsz \& Wurlianty, 2016).

Kajian ini bertujuan menilai dinamika, status dan perkembangan kelembagaan masyarakat serta implikasinya dalam pengelolaan perikanan kepiting berkelanjutan. Hasil ini dapat dijadikan contoh untuk mengembangkan model-model kelembagaan dalam pengelolaan perikanan pada KKP3K Pulau Kei Kecil dan Perairan sekitarnya secara khusus, dan secara umum pengelolaan perikanan di Kabupaten Maluku Tenggara, serta daerah lain di Indonesia.

Penelitian ini dilakukan pada Ohoi Evu, lokasi dimana kelompok pengelola perikanan kepiting (kelompok nelayan Sinar Abadi) telah dikembangkan. Penelitian ini dilakukan pada bulan Januari - Februari 2017. Pengumpulan data menggunakan teknik Semi Structured Interview (SSI) untuk data status kelembagaan, serta menggali pengetahuan seluruh pengelola sebagai responden sebanyak delapan orang, pihak Dinas Kelautan dan Perikanan empat orang dan Badan Penyuluhan Daerah Kabupaten Maluku Tenggara dua orang, dan difokuskan status Domain Kelembagaan dalam EAFM. Focus Group Discussion (FGD) dilakukan dalam penilaian perkembangan kelembagaan pengelola.

\section{BAHASAN \\ DINAMIKA KELEMBAGAAN DALAM PENGELOLAAN PERIKANAN KEPITING}

Analisis dinamika kelembagaan pengelolaan perikanan kepiting oleh masyarakat, mengacu pada penilaian tujuh indikator pada Domain Kelembagaan dalam EAFM, meliputi: 1) kepatuhan terhadap prinsipprinsip perikanan bertanggung jawab (formal dan nonformal termasuk adat); 2) kelengkapan aturan main pengelolaan perikanan; 3) mekanisme pengambilan keputusan; 4) rencana pengelolaan perikanan; 5) tingkat sinergisitas kebijakan kelembagaan; serta 6) kapasitas pemangku kepentingan (NGW-EAFM, 2014). Pengembangan analisis menggunakan beberapa metode (mix-methods). Pertama, analisis rona kelembagaan dengan pendekatan statistik deskriptif. Hasil analisis ini diekspresikan dengan sistem tabulasi, perhitungan nilai maksimum, minimum, rata-rata dan presentasi. Kedua, jastifikasi 
kondisi kelembagaan menggunakan pendekatan sistem skor sesuai dengan kriteria yang telah ditetapkan dengan skala Likert berbasis ordinal 1,2 dan 3. Ketiga, analisis untuk penentuan status setiap indikator menggunakan pendekatan flag model (Abrahamsz \& Wurlianty, 2016).

Dinamika kelembagaan dalam pengelolaan perikanan kepiting di Ohoi Evu ditunjukkan dengan variasi distribusi nilai setiap indikator. Kepatuhan terhadap prinsip-prinsip perikanan bertanggungjawab mencakup kepatuhan prinsip-prinsip perikanan bertanggung jawab dalam pengelolaan perikanan yang telah ditetapkan baik secara formal maupun non-formal atau adat. Analisis untuk melihat sejauh mana tingkat kepatuhan masyarakat terhadap aturan main secara formal dan informal dalam perikanan (NWG-EAFM, 2014).

Frekuensi pelanggaran formal tergambar dari adanya penebangan mangrove sebanyak 3-4 kali dalam setahun. Pelanggaran ini paling banyak dilakukan oleh masyarakat dari ohoi sekitar dan sering sulit dikontrol. Pelanggaran lain, terkait ukuran individu kepiting yang ditangkap dengan kisaran ukuran 11$19 \mathrm{~cm}$. Sesuai dengan ketentuan Permen KP No. 1 Tahun 2015 pasal 3 ayat 1 butir b, dari rata-rata 26 individu kepiting yang terjual dan tercatat, sebanyak $7,69 \%$ termasuk dalam ukuran tidak layak tangkap.

Pelanggaran non formal seperti mekanisme kontrol dari masyarakat dan pelaporan kepada kepala ohoi, menunjukkan pelanggaran sebanyak 4-5 kali dalam setahun, serta penebangan mangrove maupun penggunaan akar bore (bius). Mekanisme pelaporan pelanggaran berdasarkan kesekapatan di tingkat kelompok pengelola dan masyarakat.

Perilaku ilegal dalam pengelolaan perikanan kepiting disebabkan rendahnya kewajiban moral dan pengaruh sosial, orientasi biaya konvensional dan pendapatan, lemahnya kepatuhan dan mekanisme kontrol (Sutinen \& Kuperan, 1999), disamping kurangnya komunikasi otoritas pengelola dengan pengguna sumber daya (Arias \& Sutton, 2013). Banyak peraturan penangkapan kepiting bakau namun banyak nelayan tidak mengerti peraturan-peraturan tersebut karena pelaksanaan oleh pihak berwenang tidak tegas (Fitri et al., 2017). Oleh sebab itu, dibutuhkan model tatakelola yang baik melalui pengelolaan kolaboratif dan didukung kelembagaan formal dan informal untuk mereduksi kelemahan yang ada (Orchard et al., 2015).

Kelengkapan aturan main dalam pengelolaan perikanan menunjukkan rejim pengelolaan perikanan bertanggung jawab. Semakin lengkap aturan dalam pengelolaan perikanan maka semakin efektif kelembagaan pengelolaan perikanan dan pada akhirnya semakin efektif pengelolaan perikanan (NWG-EAFM, 2014). Kelengkapan peraturan nasional yang dimiliki kelompok pengelola meliputi: 1) perijinan usaha penangkapan belum dimiliki kelompok pengelola; 2) operasionalisasi penangkapan terkait pemanfaatan kepiting dan didukung proses sosialisasi Permen KP No. 1 tahun 2015; serta 3) upaya konservasi dan pemulihan meliputi peraturan tentang kawasan konservasi Kei Kecil (Kepmen KP No. 6 Tahun 2016), Permen KP No. 17 Tahun 2008, dan Permen KP No. 2 Tahun 2009, dan Permen KP No. 30 Tahun 2010. Di sisi lain, kelengkapan Peraturan Daerah dan ohoi yang dimiliki kelompok pengelola meliputi: 1) perijinan usaha penangkapan belum ada; 2) operasionalisasi penangkapan (alat tangkap bubu) melalui perijinan dari desa (aturan tidak tertulis) dan kesepakatan penempatan bubu tidak boleh tumpang tindih untuk menghindari konflik; serta 3) upaya konservasi dan pemulihan seperti penetapan kawasan hutan mangrove Hoat Sorbay sebagai kawasan lindung dalam RTRW; 4) Keputusan Bupati tentang Pencadangan KKP3K Kei Kecil; dan 5) Yutut (Sasi) hutan mangrove (aturan tidak tertulis).

Semua Peraturan Nasional telah bertambah jumlahnya sejak inisiasi pembentukan kelompok pengelola perikanan kepiting di tahun 2015, dan didukung semua Peraturan Daerah/Ohoi yang ada bertambah sejak tahun 2014 pada saat pencadangan KKP3K Kei Kecil, kecuali Yutut yang hadir lebih dari 40 tahun lalu). Walaupun terjadi peningkatan, namun kelengkapan aturan main belum mencakup seluruh domain dalam pengaturan perikanan. Hal ini terbukti dari masih belum terakomodasinya domain sosial, ekonomi dan kelembagaan.

Penegakan aturan formal belum berjalan baik, walaupun secara non formal pernah dilakukan sanksi adat pada tahun 2011 terhadap empat orang pelaku pembiusan/bore dengan membayar lela sebagai bentuk denda. Belum ada peran aparat secara khusus terkait penegakan aturan, kecuali aparat adat di tingkat ohoi yang terbatas jumlahnya. Jenis alat/ sarana untuk penegakan aturan tidak cukup (speed boat milik nelayan kepiting digunakan untuk operasi penangkapan). Sanksi adat yang diberikan tidak menimbulkan efek jera dan masih terjadi pelanggaran seperti penebangan mangrove. Demikian juga teguran dan hukuman adat tidak efektif, sehingga pelanggaran seperti penebangan mangrove masih dilakukan.

Kondisi ini menunjukkan lemahnya dinamika kelembagaan dalam pengelolaan perikanan terkait kelengkapan aturan main. Hal ini sangat ditentukan 
oleh eksistensi aturan main masih kurang, penegakan hukum lemah, dukungan peran masyarakat adat yang terbatas (Abrahamsz \& Wurlianty, 2016), serta peraturan yang telah dilakukan masih harus dioptimalkan, khususnya di bidang pengawasan dan penegakan hukum (Budiarto et al., 2015).

Penilaian mekanisme pengambilan keputusan untuk mengetahui tingkat efektivitasnya dalam pengelolaan perikanan. Pengambilan keputusan yang tidak didukung dengan tata kelola perikanan yang benar dan prinsip-prinsip perikanan yang bertanggungjawab, akan berdampak negatif bagi masa depan perikanan (NWG-EAFM, 2014). Mekanisme pengambilan keputusan dalam pengelolaan perikanan kepiting secara formal, baik untuk perijinan usaha penangkapan, operasionalisasi penangkapan kepiting maupun konservasi dan pemulihan, belum ada. Stagnasi pengembangan kelembagaan dalam masa implementasi UU 23 Tahun 2014, menyebabkan pengembangan kelembagaan lokal masih menjadi pertimbangan kewenangan Provinsi. Keputusan-keputusan hanya ada di tingkat ohoi, namun tidak dijalankan dengan baik karena belum memiliki dasar hukum tetap.

Pengambilan keputusan di tingkat masyarakat adat belum menunjukkan efektivitasnya pengelolaan perikanan. Efektivitas dapat dicapai melalui koordinasi yang kuat dengan lembaga formal di Kabupaten untuk legalisasi keputusan di tingkat masyarakat adat (Abrahamsz \& Wurlianty, 2016). Integrasi keputusan adat lintas ohoidan koordinasi dengan institusi terkait sangat membantu sosialisasi keputusan, disamping memperkuat posisi keputusan yang diambil. Nandi (2014) menyatakan implementasi kebijakan konservasi tidak hanya pada reformasi kelembagaan, namun harus disosialisasikan dan menciptakan kesadaran masyarakat.

Rencana Pengelolaan Perikanan (RPP) memuat berbagai aspek dalam pengelolaan perikanan, baik pihak-pihak terlibat, mekanisme kelembagaan dalam pengelolaan dan aspek perencanaan pengelolaan perikanan. RPP diharapkan menjadi petunjuk pelaksanaan pengelolaan sumber daya ikan dalam menjamin kesinambungan kegiatan perikanan di perairan laut (NWG-EAFM, 2014). RPP kepiting bakau belum diinisiasi instansi atau lembaga lain, kecuali di tingkat ohoi terdapat beberapa ketentuan yang disepakati bersama secara tidak tertulis. RPP kepiting bakau di ohoi Evu mesti dirumuskan dengan mengakomodasi tiga sistem utama pengelolaan, yakni sistem ekologi, sosial, dan tatakelola.
Pengaturan yang diinisiasi masyarakat termasuk Yutut atau Sasi, belum menunjukkan manfaat dalam pengelolaan. Ketergantungan ekonomi terhadap sumber daya ikan menjadi pemicu aktifitas masyarakat yang tidak sesuai dengan substansi pengaturan (Abrahamsz \& Wurlianty, 2016), bahkan dapat memicu konflik daerah penangkapan kepiting (Glaser and Diele, 2004). Penyebabnya adalah substansi pengaturan Sasi belum mengakomodasi kebutuhan pengelolaan secara komprehensif (Abrahamsz \& Wurlianty, 2016). Padahal, eksistensi RPP sangat menentukan keberhasilan pengelolaan perikanan berkelanjutan (Fletcher et al., 2010). Pilihan terbaik membangun RPP adalah penggunaan sistem pengelolaan perikanan dengan pendekatan ekosistem. Pilihan ini sangat membantu lembaga pengelola mereduksi dampak yang kompleks.

Tingkat sinergisitas antar kebijakan dan lembaga merupakan keterpaduan gerak dan langkah antar lembaga dan antar kebijakan dalam pengelolaan perikanan sehingga tidak memunculkan konflik kepentingan dan benturan kebijakan. Keberhasilan pengelolaan perikanan ditentukan oleh sejauhmana sinergisitas antar lembaga (NWG-EAFM, 2014).

Pada tingkat Kabupaten, ada koordinasi antara Bappeda, DKP dan Badan Penyuluh dalam membangun kesepakatan pengembangan kelembagaan pengelola perikanan kepiting berbasis masyarakat. Hal ini dibuktikan dengan dukungan Bappeda dan DKP terhadap SK pembentukan Kelompok Pengelola Kelompok Nelayan Abadi yang dikeluarkan oleh Badan Penyuluhan melalui SK Kepala BP4K No. 526.1/800/14/BP4K/IV/2016 tentang Pengukuhan Kelas Kelembagaan Pelaku Utama Perikanan Kabupaten Maluku Tenggara Tahun 2016.

Pada tingkat kawasan, telah dilakukan koordinasi dan sosialisasi antar lembaga adat di sekitar kawasan untuk mendukung pengelolaan perikanan kepiting di ohoi Evu. Walaupun demikian, belum terbangun komunikasi yang baik antar kelembagaan adat, sehingga masih ada pengrusakan mangrove oleh masyarakat dari ohoi tetangga. Di sisi lain, pengakuan terhadap kelompok pengelolaan perikanan kepiting Sinar Abadi, didukung dengan Piagam Pengukuhan Kelas Kelompok Pemula.

Sinergisitas antar lembaga belum didukung dengan komunikasi yang efektif, namun pada tingkat kebijakan terindikasi saling mendukung. Glaser and Diele (2004) menyatakan tantangan bagi upaya membangun sinergitas antar lembaga adalah penetapan prioritas pengelolaan perikanan yang 
relevan dengan partisipasi aktif dari stakeholder. Sinergitas juga dibutuhkan untuk mengimplementasi strategi pendampingan dan penguatan kelembagaan dalam mendukung pengelolaan perikanan kepiting, khususnya melalui jaminan pelaksanaan aturanaturan di tingkat lokal (Fitri et al., 2017), serta penguatan model pengelolaan berbasis masyarakat yang mampu berkolaborasi dengan institusi formal (Berkes, 2006).

Kapasitas pemangku kepentingan mencakup upaya konstruktif peningkatan kapasitas oleh pemangku kepentingan. Pemangku perikanan adalah berbagai pihak yang terkait secara langsung dalam pengelolaan perikanan. Pemangku perikanan dapat berasal dari birokrasi pemerintah (pusat dan daerah), swasta, masyarakat, perguruan tinggi, LSM dan organisasi masyarakat pesisir. Tujuan penilaian indikator untuk mengetahui upaya peningkatan kapasitas pemangku kepentingan dalam kerangka EAF (NWG-EAFM, 2014).

Upaya peningkatan kapasitas pemangku kepentingan terkait pengelolaan perikanan kepiting dan kegiatan pendukung lain telah diikuti sejak tahun 2013, antara lain: 1) workshop/ pelatihan konservasi;
2) studi banding transplantasi karang; 3) studi banding pengelolaan kawasan konservasi; 4) pelatihan EAFM untuk tingkat pelaksana dan masyarakat; 5) pelatihan terkait zonasi WP3K secara umum dan pengelolaan kawasan konservasi secara khusus. Penerapannya mulai diinisiasi dalam bentuk pengembangan berbagai program dan kegiatan pengelolaan perikanan kepiting. Namun demikian, alokasi peran sesuai kapasitas masing-masing belum banyak mendapat perhatian.

Efektivitas peningkatan kapasitas dalam pengelolaan perikanan sangat ditentukan oleh kebijakan yang diimplementasi (Abrahamsz \& Wurlianty, 2016), proses pembelajaran antar individu, antar displin, dan antar tipe pengetahuan, serta pilihan inidvidu yang memperhatikan posisi dan fungsi sesuai tugas pokoknya (Haapasaari et al., 2012). Secara agregat, analisis dinamika kelembagaan berada pada status sedang (Tabel 1). Analisis dinamika kelembagaan dalam mendukung pengelolaan sumberdaya kepiting menunjukan masih ada kebutuhan penguatan kelembagaan formal dan informal. Strategi penguatan dan implikasinya bagi pengelolaan perikanan kepiting perlu didukung pengetahuan status dan perkembangan kelembagaan.

Tabel 1. Hasil penilaian indikator-indikator domain kelembagaan dan deskripsi statusnya

Table 1. Assessment results of institutional domain indicators and status descriptions

\begin{tabular}{lcc}
\hline \multicolumn{1}{c}{ Indikator } & Nilai & Deskripsi \\
\hline $\begin{array}{l}\text { 1. Kepatuhan terhadap prinsip-prinsip perikanan yang bertanggung } \\
\text { jawab }\end{array}$ & 2 & Sedang \\
$\begin{array}{l}\text { 2. Kelengkapan aturan main dalam pengelolaan perikanan } \\
\text { 3. Mekanisme pengambilan keputusan }\end{array}$ & 2 & Sedang \\
$\begin{array}{l}\text { 4. Rencana pengelolaan perikanan } \\
\text { 5. Tingkat sinergisitas kebijakan dan kelembagaan pengelolaan } \\
\text { perikanan }\end{array}$ & 2 & Sedang \\
6. Kapasitas pemangku kepentingan & 3 & Buruk \\
\hline
\end{tabular}

\section{STATUS DAN PERKEMBANGAN KELEMBAGAAN}

Analisis status dan perkembangan kelembagaan menggunakan pendekatan Institutional Development Framework (IDF) yang dikembangkan dari Kirana dan Malik (2000) dan model perhitungan Indeks IDF menurut Yulianto et al. (2011). Analisis ini dibangun secara bertahap masing-masing: 1) menyusun Matriks Kerangka Kerja Pengembangan Institusi; 2) kalkulasi indeks perkembangan institusi dan analisis grafis profil perkembangan institusi; 3 ) penentuan prioritas komponen kunci (skoring dan ranking prioritas); serta 4) perencanaan pengembangan institusi yang menjadi input dalam memperkuat perumusan implikasi pengelolaan. Perumusan implikasi pengembangan kelembagaan dalam mendukung pengelolaan perikanan kepiting berdasarkan hasil penilaian dinamika, status dan perkembangan kelembagaan. Pengembangan visi kelembagaan pada Indeks IDF tertinggi, yaitu 3,17. Status dan perkembangan kelembagaan pengelola perikanan kepiting berdasarkan pengembangan visi kelembagaan, termasuk tahapan keberlanjutan. Namun, upaya-upaya memajukan organisasi masih membutuhkan perhatian serius. Sumber daya manajemen kelembagaan dengan Indeks IDF pada nilai 2,77 , berada pada tahapan pemantapan. Sistem monitoring dan evaluasi terintegrasi merupakan komponen kunci yang harus ditingkatkan fungsinya. 
Sumber daya manusia termasuk dalam kategori rendah, sesuai Indeks IDF pada nilai 1,89. Masih ada kebutuhan dalam peningkatan kapasitas sumber daya manusia karena masih termasuk dalam tahapan perkembangan. Strategi peningkatan kapasitas mesti diarahkan pada komponen kunci partisipasi anggota dalam manajemen, keahlian anggota, pengembangan profesi, penilaian kinerja, pengangkatan anggota lokal/ jender, dan komposisi anggota.

Sumber daya keuangan juga termasuk dalam ketegori rendah, dimana Indeks IDF terdistribusi pada nilai 1,92. Komponen-komponen kunci yang membutuhkan peningkatan kapasitas dan pengembangan secara serius meliputi pengendalian keuangan, mekanisme kontrol pengelolaan keuangan, strategi penghimpunan dana, dan kapasitas keuangan.

Sumber daya eksternal termasuk paling rendah, sesuai Indeks IDF pada nilai 1,74. Dari tujuh komponen kunci yang dinilai, lima di antaranya membutuhkan upaya-upaya penguatan atau pengembangan, antara lain: kemampuan kerjasama dengan masyarakat lokal, advokasi masyarakat lokal, komunikasi badan pengelola, kemampuan kerjasama dengan pemerintah dan kemampuan mengakses sumber daya lokal.

Isu-isu spesifik pengelolaan sumber daya kepiting yang menjadi perhatian kelembagaan pengelola mulai masuk dalam kategori cukup. Status ini sesuai dengan Indeks IDF pada nilai 2,00, yang membuktikan masih ada komponen kunci yang harus dikelola dengan baik. Beberapa komponen kunci yang penting menjadi perhatian dalam sumber daya kelembagaan ini meliputi: praktek-praktek pengelolaan sumber daya kepiting, resolusi konflik atas sumber daya kepiting, dan pelaksanaan peraturan pengelolaan sumber daya kepiting.

Secara agregat, status kelembagaan pengelola perikanan kepiting bakau di Ohoi Evu termasuk dalam kategori cukup. Kondisi ini berpengaruh dalam menentukan perkembangan lembaga pengelola pada tahap pemantapan. Posisi kelembagaan pada tahapan ini sesuai Indeks IDF agregat 2,25, dimana perkembangan kelembagaan pengelola perikanan kepiting berada pada tingkatan paling bawah, yaitu tahap pemantapan.

Ekspresi grafis hubungan ranking prioritas dan skor perkembangan kelembagaan pengelola perikanan kepiting di Ohoi Evu (Gambar 1), mengindikasi kinerja pengembangan visi kelembagaan, sumber daya manajemen dan isu-isu spesifik pengelolaan sumber daya kepiting harus dipertahankan sambil membenahi setiap komponen kunci yang masih rendah. Di sisi lain, sumber daya manusia, sumber daya keuangan dan sumber daya eksternal masih membutuhkan upaya-upaya peningkatan. Kirana \& Malik (2000) menjelaskan, jika sumber daya kelembagaan terdistribusi pada kuadran kanan atas, maka kinerja harus dipertahankan. Jika sumber daya kelembagaan terdistribusi pada kuadran kanan bawah, maka kapasitas kelembagaan seperti ini, paling mendesak untuk segera ditingkatkan.

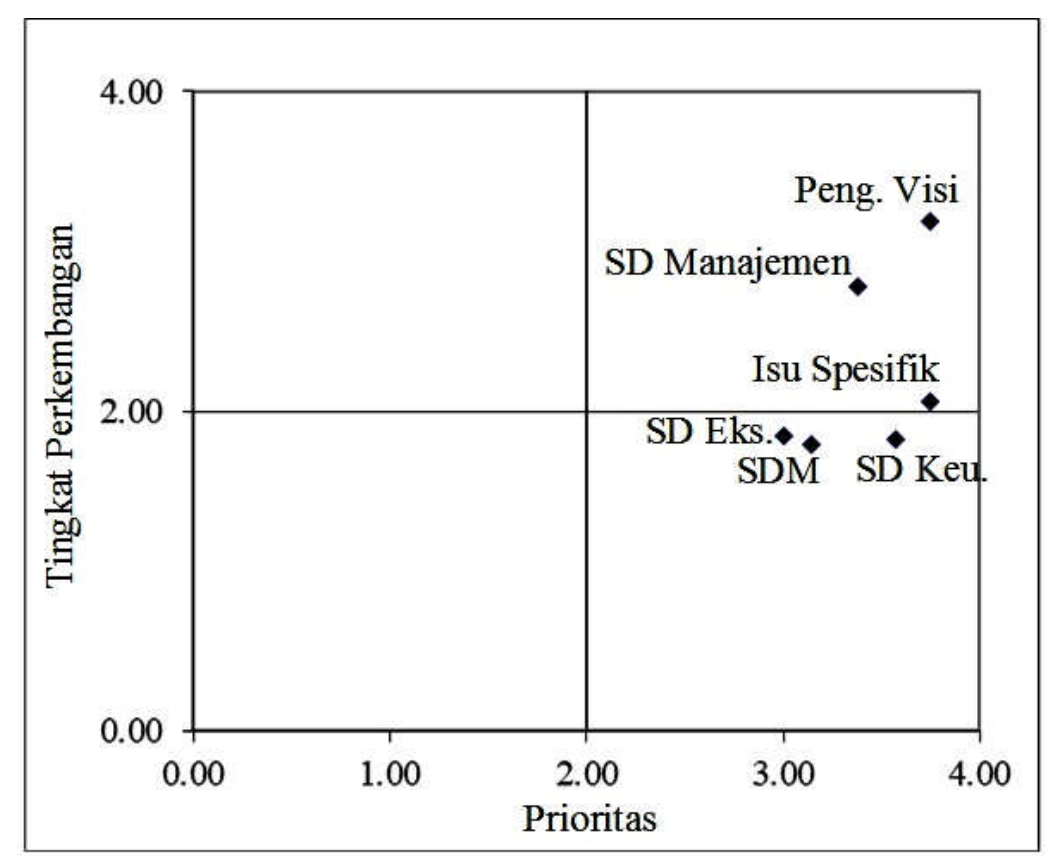

Gambar 1.Grafik Prioritas Pengembangan Kelembagaan.

Figure 1. Priority Chart of Institutional Development. 
IMPLIKASI PENGEMBANGAN KELEMBAGAAN PENGELOLA PERIKANAN KEPITING

Dinamika kelembagaan yang berada pada nilai sedang, berimplikasi terhadap adanya kebutuhan peningkatkan kinerja kelembagaan. Demikian halnya dengan status kelembagaan dalam kategori nilai cukup, dan perkembangan lembaga pengelola pada tahap pemantapan, berimplikasi terhadap adanya kebutuhan pembenahan aspek manajemen dalam lembaga dan peningkatan kapasitas kelembagaan.

Analisis dinamika kelembagaan dengan instrumen domain kelembagaan EAFM memberikan implikasi pengembangan kelembagaan, antara lain: 1) peningkatan pengawasan dan sosialisasi prinsipprinsip perikanan kepiting bertanggungjawab; 2) sosialisasi dan fasilitasi peraturan-peraturan terkait pengelolaan perikanan kepiting bakau; 3) penegakan aturan di tingkat lokal dan kawasan; 4) perumusan dan membangun kesekapatan tentang mekanisme pengambilan keputusan yang didukung dengan Standart Operating Procedure (SOP); 5) penyusunan dan sosialisasi Rencana Pengelolaan Perikanan (RPP) kepiting bakau; 6) penguatan kapasitas kelembagaan dalam membangun sinergitas program dengan pemerintah daerah dan stakeholder lain; serta 7) peningkatan kapasitas kelompok mulai dari pembina, pengelola kelembagaan dan masyarakat lokal.

Terkait dengan status dan perkembangan kelembagaan, peningkatan kapasitas sumber daya manusia pengelola yang diarahkan pada peningkatan partispasi dalam pengelolaan kelembagaan, peningkatan keahlian pengelola sesuai pembagian tugas, pengembangan mata pencaharian alternatif, kapasitas penilaian kinerja, perekrutan anggota yang menunjukkan keterwakilan masyarakat secara umum dan berbasis jender. Peningkatan kapasitas sumber daya keuangan melalui diversifikasi sumber-sumber pendanaan, pengembangan dan pembinaan kemitraan dengan lembaga keuangan serta peningkatan kapasitas sumber daya manusia pengelola keuangan. Pengembangan kemitraan dengan lembaga pemerintah, lembaga pendidikan, lembaga keuangan dan lembaga-lembaga swadaya masyarakat, yang didukung dengan pengembangan sistem informasi dan promosi terhadap eksitensi kelembagaan pengelola perikanan kepiting bakau di OhoiEvu.

Implikasi pengembangan kelembagaan pengelola ini dipandang penting oleh Cinner et al. (2012) yang menyatakan bahwa pengelolaan perikanan bisa sukses tergantung pemahaman kondisi sosial dan kelembagaan yang kuat dalam meningkatkan kepatuhan. Winter (2009) menyatakan pendekatanpendekatan pengelolaan perikanan yang baik sangat ditentukan oleh ukuran-ukuran pengelolaan dan pengaruh-pengaruhnya, dan dapat dibingkai sebagai praktek aturan main terbaik dalam pengelolaan berkelanjutan. McClanahan (2014) berpendapat pada tingkat nelayan secara individual, peningkatan kapasitas dan partispasi mereka merupakan upaya untuk meningkatkan dukungan terhadap pengelolaan berkelanjutan. Pada kondisi ini, adopsi aturan pengelolaan akan berjalan dengan baik karena meningkatnya kepatuhan dalam pengelolaan perikanan. Untuk keberlanjutan kelembagaan, Datta et al (2012) merekomendasi restrukturisasi kelembagaan pengelola mangrove berbasis masyarakat, dengan memastikan partisipasi pengguna dalam pengambilan keputusan dan pembagian sumber daya.

\section{KESIMPULAN DAN REKOMENDASI Kesimpulan}

Dinamika kelembagaan pengelola perikanan kepiting bakau di Ohoi Evu tergolong dalam kategori sedang. Pada kategori ini, upaya peningkatan kapasitas kelembagaan pengelola difokuskan pada penetapan rencana pengelolaan perikanan kepiting. Di sisi lain, kepatuhan, kelengkapan aturan main dan mekanisme pengambilan keputusan masih harus dioptimalkan.

\section{Rekomendasi}

Status kelembagaan pada kategori cukup dan perkembangannya pada tahap pemantapan, membutuhkan peningkatan kapasitas sumberdaya manusia melalui pelatihan dan pendidikan, sumberdaya eksternal dikembangkan melalui peningkatan kemitraan, serta peningkatan sumberdaya keuangan melalui kemandirian keuangan dan jejaring pendanaan.

\section{PERSANTUNAN}

Tulisan ini merupakan bagian dari kerjasama penelitian Yayasan WWF Indonesia dengan Learning Center EAFM Universitas Pattimura. Penghargaan disampaikan kepada Yayasan WWF Indonesia yang telah memberikan kesempatan pengembangan kajian ini, serta Dinas Kelautan dan Perikanan Kabupaten Maluku Tenggara yang telah memfasilitasi tim peneliti selama proses penelitian. 


\section{DAFTAR PUSTAKA}

Abrahamsz, J., \& Wurlianty, B. (2016). Dinamika kelembagaan dalam pengelolaan perikanan karang berkelanjutan pada kawasan konservasi kongsnuden, kabupaten seram bagian timur. Dalam Simposium Nasional Pengelolaan Perikanan Karang Berkelanjutan Indonesia (pp. 379-393). Bali, Indonesia: Kementerian Kelautan dan Perikanan Republik Indonesia, COREMAPCTI, dan WWF-Indonesia.

Arias, A., \& Sutton, SG. (2013). Understanding recreational fishers' compliance with no-take zones in the Great Barrier Reef Marine Park. Ecology and Society. 18(4), 18-26.

Berkes, F. (2006). From community-based resource management to complex systems: The Scale Issue and Marine Commons. Ecology and Society 11(1), 45-59.

Budiarto, A., Adrianto, L., \& Kamal, M. (2015). Status pengelolaan perikanan rajungan (Portunus pelagicus) dengan pendekatan ekosistem di Laut Jawa (WPPNRI 712). J.Kebijak.Perik.Indonesia, 7 (1), 9-24.

Charles, A. (2001). Sustainable fishery systems (p. 370) Victoria: Blackwell Science Ltd.

Cinner, J.E., Wamukota, A., Randriamahazo, H., \& Rabearisoa, A. (2009). Toward institutions for community-based management of inshore marine resources in the western Indian Ocean. Marine Policy, 33(3), 489-496.

Cinner, J.E., Daw, T.M., McClanahan, TR., Muthiga, N., Abunge, C., Hamed, S., Mwaka, B. Rabearisoa, A., Wamukota, A., Fisher, E., \& Jiddawi, N. (2012). Transitions toward comanagement: the process of marine resource management devolution in three east African countries. Global Environmental Change, 22(3), 651-658.

Dahuri, R., Rais, J., Ginting, SP., \& Sitepu, M.J. (2004). Pengelolaan sumber daya wilayah pesisir dan lautan secara terpadu. Cetakan Ketiga, Edisi Revisi. Pradnya Paramita. Jakarta. p. 328.

Datta, D., Chattopadhyay, R.N., \& Guha, P. (2012). Community based mangrove management: $A$ review on status and sustainability. Journal of Environmental Management. 107, 84-95.
Fitri, A.D.F., Boesono, H., Sabdono, A., \& Adlina, N. (2017). Resources management strategy for mud crabs (Scylla spp.) In Pemalang Regency. Earth and Environmental Science, 10 (2), 191-199.

Glaser M., \& Diele, K. (2004). Asymmetric outcomes: assessing central aspects of the biological, economic and social sustainability of a mangrove crab fishery, Ucides cordatus (Ocypodidae), in North Brazil. Ecological Economics, 49 (3), 361373.

Haapasaari, P., Kulmala, S., \& Kuikka, S. (2012). Growing into Interdisciplinarity: How to Converge Biology, Economics, and Social Science in Fisheries Research? Ecology and Society, 17(1), 6.

Keputusan Menteri Kelautan dan Perikanan Nomor 6 Tahun 2016 tentang Kawasan Konservasi Pesisir dan Pulau-Pulau Kecil Pulau Kei Kecil, PulauPulau, dan Perairan Sekitarnya di Kabupaten Maluku Tenggara Provinsi Maluku.

Kirana, C \& Malik, I. (2000). Kerangka kerja pengembangan institusi: Manual Untuk Pengguna. BSP Kemala, Jakarta. p. 55.

McClanahan, TR., Cinner, J.E., Abunge, C., Rabearisoa, A., Mahatante, P., Ramahatratra, F., \& Andrianarivelo, $N$ (2014). Perceived benefits of fisheries management restrictions in Madagascar. Ecology and Society, 19 (1), 5-15.

Nandi. (2014). Coastal conservation policies and integrated coastal zone management (ICZM) in Indonesia. International Journal of Conservation Science, 5 (3), 387-396.

NWG-EAFM. (2014). Penilaian indikator untuk pengelolaan perikanan dengan pendekatan ekosistem (Ecosystem Approach to Fisheries Management). Modul. Direktorat Sumber daya Ikan, Kementerian Kelautan dan Perikanan Republik Indonesia. p.197.

Orchard, S.E., Stringer, L.C., \& Quinn, CH (2015). Environmental entitlements: Institutional Influence on Mangrove Social-Ecological Systems in Northern Vietnam. Resources, (4), 903-938.

Peraturan Menteri Kelautan dan Perikanan Nomor 9 Tahun 2015 tentang Standar Kompetensi Kerja Khusus Pengelolaan Perikanan Dengan Pendekatan Ekosistem. 
Suman, A., Irianto, H.E., Satria, F., \& Amri, K. (2016). Potensi dan tingkat pemanfaatan sumber daya ikan di wilayah pengelolaan perikanan Negara Republik Indonesia (WPP NRI) Tahun 2015 serta Opsi Pengelolaannya. J.Kebijak.Perik.Indonesia, 8 (2), 97-110.

Sutinen, J. G., \& Kuperan, K. (1999). A socioeconomic theory of regulatory compliance. International Journal of Social Economics, 26(13), 174-193.

Tim Perikanan WWF-Indonesia (2015). Better management practices: Seri Panduan Perikanan
Skala Kecil Kepiting Bakau (Scylla sp.). Panduan Penangkapan dan Penanganan. Edisi 1, Februari 2015. 36 hal.

Winter, G (2009). Towards sustainable fisheries law: A comparative analysis. IUCN Environmental Policy and Law Paper, No. 74. P. 321.

Yulianto, I., Wiryawan, B., \& Taurusman, AA. (2011). Strategi dan rekomendasi pengelolaan perikanan karang berdasarkan status kelembagaan. Marine Fisheries, 2 (2), 121-127. 